\title{
STRATEGI PENINGKATAN PENERIMAAN PAJAK HOTEL DI KOTA SUKABUMI
}

\author{
Mitha Virnawati ${ }^{(1)}$ \\ Dedi Budiman Hakim ${ }^{(2)}$ \\ A. Faroby Falatehan ${ }^{(3)}$ \\ (1) Magister Sains Manajemen Pembangunan Daerah-IPB \\ (2), (3)Fakultas Ekonomi dan Manajemen -Institut Pertanian Bogor \\ email : mitha26poenya@gmail.com
}

\begin{abstract}
ABSTRAK
Pajak hotel merupakan salah satu dari pajak daerah yang memiliki potensi besar untuk ditingkatkan sebagai salah satu sumber pendapatan asli daerah (PAD). Pajak hotel di Kota Sukabumi masih lebih kecil dibandingkan dengan pajak daerah yang lainnya, sehingga dibutuhkan strategi dalam peningkatan penerimaannya. Penelitian ini menggunakan dua buah jenis data yakni data primer dan data sekunder. Metode analisis yang digunakan adalah rasio pertumbuhan dan kontribusi, rasio efektivitas dan efisiensi, dan analytical hierarchy process. Tujuan dari penelitian ini adalah untuk mengetahui tingkat pertumbuhan dan kontribusi pajak hotel terhadap pendapatan asli daerah, tingkat efektivitas dan efisiensi pemungutan pajak hotel, dan merumuskan strategi peningkatan penerimaan pajak hotel di Kota Sukabumi. Berdasarkan hasil penelitian, dapat ditarik kesimpulan bahwa rata-rata tingkat pertumbuhan pajak hotel sebesar $13.18 \%$, rata-rata tingkat kontribusi pajak hotel terhadap pajak daerah sebesar $3.91 \%$, dan rata-rata kontribusi pajak hotel terhadap pendapatan asli daerah sebesar $0.47 \%$ dengan kriteria sangat kurang, rata-rata tingkat efektivitas pajak hotel sebesar $107.93 \%$ dengan kategori sangat efektif dan rata-rata tingkat efisiensi sebesar 5.67\% dengan kategori sangat efisien. Untuk peningkatan penerimaan pajak hotel dibutuhkan strategi melalui perbaikan sistem pengelolaan dan pengawasan, peningkatan sosialisasi dan penegakan hukum, promosi wisata, sarana prasarana, dan kualitas SDM.
\end{abstract}

Kata Kunci : pajak hotel, peningkatan, kota sukabumi, strategi

\begin{abstract}
Hotel tax is one of a local tax that has great potential to be increased as one source of local government revenue $(P A D)$. Revenue from hotel tax in the City of Sukabumi is smaller when compared to other local taxes, so it needs strategies to increase its income revenue. This research included descriptive research type with using primary and secondary data. Analysis methods used were growth and contribution ratio, effectiveness and efficiency ratio, and analytical hierarchy process. The purposes of this research were to determine the growth rate and the contribution of hotel tax to local revenue, to measure the effectiveness and efficiency of hotel tax and to determine the strategies in the implementation of revenue hotel tax. The result of this research presented on average the growth of hotel tax revenue was $13.18 \%$. Its contribution to local taxes averaged of $3.91 \%$, and contribution to local government revenue averaged of $0.47 \%$ with category is very low, the average effectiveness rate of $107.93 \%$ with the category of very effective and the efficiency level 5.67 $\%$ with the category highly efficient. To increase the hotel tax revenues requires strategies by improving the system of management and supervision, socialization and low enforcement, tourism promotion, infrastructure facilities, and quality of human resources.
\end{abstract}

Keywords : hotel tax, increasing, strategy, sukabumi city

\section{PENDAHULUAN}

Indonesia telah melaksanakan otonomi daerah dan desentralisasi fiskal sejak tahun 2001 dengan tujuan mempercepat pertumbuhan ekonomi dan pembangunan daerah, mengurangi kesenjangan antar daerah serta meningkatkan kualitas pelayanan publik agar lebih efisien dan responsif terhadap kebutuhan, potensi, maupun karakteristik di setiap daerah. Otonomi daerah mulai diberlakukan pada masa orde baru berakhir (Rusmana et al., 2011). Otonomi daerah menjadi strategi yang efektif untuk peningkatan pertumbuhan ekonomi dan pembangunan suatu daerah. Desentralisasi diharapkan dapat merangsang pertumbuhan dan perkembangan ekonomi di suatu daerah (Ikeji, 2011). Sepuvelda dan Vazquez (2010), mengatakan bahwa penurunan kemiskinan dan ketimpangan distribusi pendapatan merupakan dampak langsung dan tidak 
langsung dari adanya kebijakan otonomi daerah dimana pemerintah daerah memiliki peranan penting melalui kebijakan yang terbuka dan langsung. Konsekuensi dari pelaksanaan otonomi daerah terletak pada kesiapan dan kemampuan daerah untuk menerima beban dan tanggungjawab yang dimilikinya dalam mengatur serta mengurus rumah tangganya sendiri. Daerah harus mampu meningkatkan sumber penerimaan daerah dalam rangka menjamin kemampuan keuangan daerah tersebut. Dalam rangka pelaksanaan penyelenggaraan pembangunan daerah dan menunjang pemerintahan daerahnya, pemerintah daerah berhak mengenakan pemungutan pajak daerah dan retribusi daerah kepada seluruh warga masyarakatnya (Ismail, 2011). Pelimpahan wewenang dari Pemerintah Pusat kepada Pemerintah Daerah, menuntut daerah harus dapat lebih aktif dalam menggali sumber-sumber pendapatan daerah yang potensial dan meminimalkan ketergantungan pada sumber dana dari pemerintah pusat (Hoque \& Adams, 2008).

Pelimpahan kebijakan otonomi daerah akan mengalami suatu permasalahan bagi daerah-daerah yang tidak memiliki potensi sumber daya yang mumpuni sehingga bagi daerah tersebut mengganggap otonomi daerah tidak menguntungkan bagi daerahnya (Norregaard, 2013). Namun menurut Poulson dan Kaplan (2008), mengatakan hal lain bahwa setiap daerah otonomi baik provinsi maupun Kab/Kota memiliki sumber daya alam dan potensi ekonomi yang beranekaragam sehingga apabila potensi dari masing-masing daerah dapat dioptimalkan maka akan memberikan kontribusi kepada pendapatan daerah masing-masing untuk melaksanakan pembangunan daerah.

Kota Sukabumi mempunyai tujuan ke depan dalam hal kesejahteraan masyarakat dan kemandirian daerah. Sebagai upaya peningkatkan Pendapatan Asli Daerah (PAD) dengan menggali sumber-sumber pendapatan daerah, salah satunya melalui penggalian potensi pajak. Dengan penggalian potensi yang ada akan meningkatkan penerimaan daerah. Pajak daerah dikelola oleh pemerintah daerah, baik pemerintah provinsi maupun kabupaten atau kota sebagai penunjang penerimaan Pendapatan Asli Daerah (PAD) yang menjadi salah satu sumber pembiayaan daerah yang paling utama dalam memajukan serta mengembangkan daerah yang menyangkut kepentingan rakyat banyak (Tang et al., 2011).

Jenis pajak daerah yang dapat dipungut terdiri dari 11 (sebelas) jenis pajak yaitu pajak hotel, pajak restoran, pajak hiburan, pajak reklame, pajak penerangan jalan, pajak mineral bukan logam dan batuan, pajak parkir, pajak air tanah, pajak sarang burung walet, pajak bumi dan bangunan perdesaan perkotaan, serta pajak perolehan hak atas tanah dan bangunan. Dari sebelas jenis pajak tersebut saat ini terdapat 9(sembilan) jenis pajak daerah yang sudah dipungut oleh pemerintah Kota Sukabumi yaitu pajak hotel, pajak restoran, pajak hiburan, pajak reklame, pajak penerangan jalan, pajak parkir, pajak air tanah, Bea Perolehan Hak Atas Tanah dan Bangunan (BPHTB), dan Pajak Bumi dan Bangunan Perkotaan Pedesaan (PBB P2).

Tabel 1. Data Realisasi Pajak Daerah Kota Sukabumi Tahun 2011-2015 (dalam persentase)

\begin{tabular}{lllllll}
\hline No & \multicolumn{1}{c}{ Jenis Pajak Daerah } & \multicolumn{5}{c}{ Tahun } \\
\cline { 3 - 6 } & & 2011 & 2012 & 2013 & 2014 & \multicolumn{1}{c}{2015} \\
\hline 1. & Pajak Hotel & 117.42 & 109.50 & 109.09 & 95.56 & 108.05 \\
2. & Pajak Restoran & 102.13 & 108.10 & 116.71 & 121.88 & 116.83 \\
3. & Pajak Hiburan & 97.75 & 99.72 & 114.68 & 96.37 & 114.44 \\
4. & Pajak Reklame & 110.30 & 109.90 & 104.03 & 95.45 & 105.66 \\
5. & Pajak Penerangan Jalan & 118.27 & 114.77 & 122.56 & 105.41 & 88.27 \\
6. & Pajak Parkir & 104.85 & 101.13 & 100.74 & 46.82 & 100.23 \\
7. & Pajak Air Tanah & 139.35 & 110.09 & 49.54 & 93.74 & 110.82 \\
8. & PBB & - & - & - & 109.11 & 103.66 \\
9. & BPHTB & 118.00 & 131.36 & 140.28 & 113.51 & 111.45 \\
\hline
\end{tabular}

Sumber: Badan Pengelolaan Keuangan Daerah Kota Sukabumi (diolah)

Tabel 1 menunjukkan bahwa realisasi dari target yang ditetapkan selama periode 5 (lima) tahun anggaran Kota Sukabumi dengan pencapaian realisasi dari setiap jenis pajak dalam setiap tahunnya ada beberapa yang tidak tercapai (dibawah 100\%). Pada tahun 2011 dan tahun 2012 yang tidak tercapai target adalah pajak hiburan berturut-turut. Tahun 2013 pencapaian penerimaan dibawah target adalah 
pajak air tanah. Pada tahun 2014 Pajak Bumi dan Bangunan Pedesaan Perkotaan (PBB P2) mulai dikelola oleh pemerintah Kota Sukabumi dan pada tahun yang sama juga ada 5(lima) jenis pajak daerah yang tidak mencapai target yaitu: pajak hotel, pajak hiburan, pajak reklame, pajak parkir, dan pajak air tanah. Tahun 2015 mengalami peningkatan dari kelima pajak yang tidak tercapai tersebut di tahun 2014, tetapi ada satu jenis pajak yang tidak tercapai yaitu pajak penerangan jalan (88.27\%).

Kota Sukabumi merupakan salah satu kota yang strategis karena berada pada jalur lintasan ibukota provinsi Jawa Barat (Bandung), Kota Sukabumi juga memiliki keunggulan kompetitif lainnya, selain wilayahnya yang berdekatan dengan Kabupaten Sukabumi yang notabene memiliki banyak tempat wisata alam, juga berada di bawah kaki gunung yang hawanya masih sejuk sehingga banyak menarik minat wisatawan datang ke Kota Sukabumi untuk menjadikannya sebagai tempat kegiatan bisnis, sekedar menginap atau berwisata kuliner. Dengan kedatangan banyaknya wisatawan tersebut, maka akan secara otomatis membuka peluang bagi para investor untuk berinvestasi di bidang pariwisata seperti tempat bermain, tempat menginap (hotel, wisma, homestay), restoran, jasa, warung, angkutan dan lain-lain yang akan berdampak juga kepada perekonomian masyarakat lokal dan memberikan peluang bagi Pemerintah Kota Sukabumi untuk menggali sumber pendapatan asli daerah salah satunya dari pajak hotel. Dimana sektor pariwisata merupakan salah satu faktor yang mempengaruhi PAD melalui Pajak Hotel, karena memiliki potensi yang besar untuk dikembangkan.

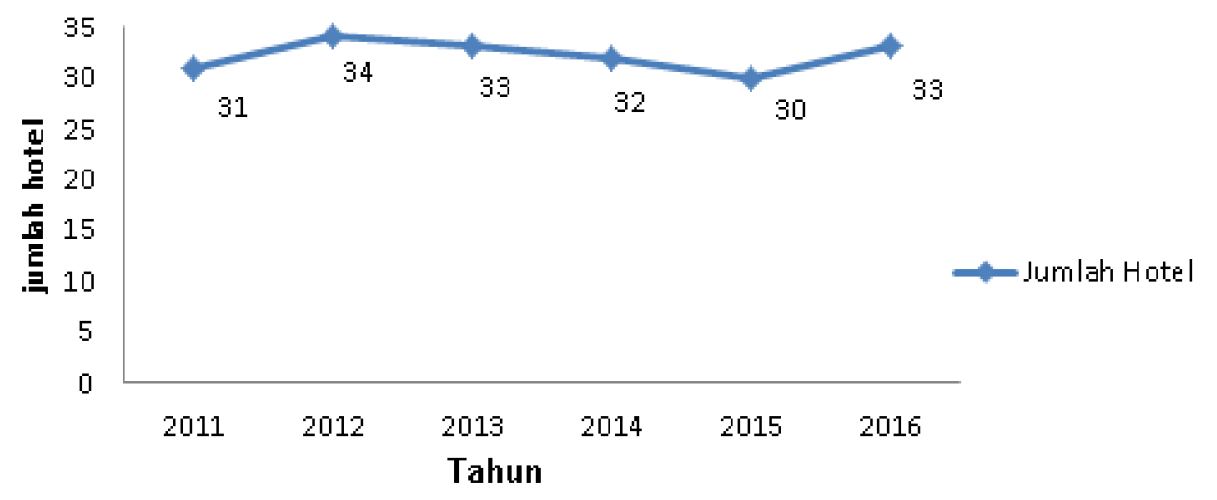

Gambar 1. Perkembangan Jumlah Hotel di Kota Sukabumi Tahun 2011-2016

Sumber: Badan Pengelolaan Keuangan Daerah Kota Sukabumi (2016)

Gambar 1 menunjukkan perkembangan jumlah hotel yang ada di Kota Sukabumi mengalami naik turun, dimana pada tahun 2012 adanya penambahan 3 hotel baru yang telah dibuka yaitu Hotel A Rondari, Hotel Pakidulan dan Hotel Jazz. Tahun 2013 mengalami penurunan dimana ada satu hotel yang tutup yaitu Hotel Cattelya. Tahun 2014 ada satu penginapan yang tutup yaitu Penginapan Maru dan tahun 2015 ada tiga hotel yang tutup yaitu Hotel Juwita, Hotel Batu Putih, dan Hotel Resik, tetapi ada satu hotel yang baru buka yaitu Hotel Maxone. Tahun 2016 mengalami kenaikan, dimana ada tiga hotel yang baru dibuka yaitu Hotel Horison, Hotel Balcony, dan Hotel Fresh. Dapat disimpulkan bahwa selama periode tahun 2011-2016 ada lima hotel yang sudah tutup, tetapi ada tujuh pembangunan hotel baru. Perkembangan tersebut cukup baik, mengingat bahwa luas Kota Sukabumi yang hanya seluas 48.96 $\mathrm{KM}^{2}$, dan tersebar di tiga Kecamatan dari tujuh Kecamatan yang ada, yaitu Kecamatan Cikole, Warudoyong, dan Gunung Puyuh.
Pemerintah Kota Sukabumi mendukung dan mengelola pajak hotel telah menerbitkan peraturan yang tertuang dalam Peraturan Daerah Kota Sukabumi Nomor 7 Tahun 2011 tentang Pajak Hotel. Berdasarkan Badan Pengelola Keuangan Daerah (2016), realisasi penerimaan pajak hotel selama tahun 2011-2015 setiap tahunnya diatas $100 \%$, tetapi pada tahun 2014 hanya tercapai $95.55 \%$. Pencapaian pajak hotel belum maksimal karena dalam kurun waktu 5 tahun terakhir kontribusinya terhadap PAD kota Sukabumi masih sangat kecil dan menurun setiap tahunnya. Untuk itu Pemerintah Kota Sukabumi tetap harus berupaya meningkatkan penerimaan daerah melalui pajak hotel.

Berdasarkan uraian di atas, permasalahan yang akan dirumuskan adalah 1) Bagaimana pertumbuhan dan kontribusi penerimaan pajak hotel di Kota Sukabumi dari tahun 2011-2015? 2) Bagaimana tingkat efektivitas dan efisiensi pada pemungutan penerimaan pajak hotel di Kota Sukabumi dari tahun 2011-2015? 3) Bagaimana merumuskan strategi 
dalam meningkatkan penerimaan pajak hotel yang dilakukan Pemerintah Daerah Kota Sukabumi? Tujuan dilakukan penelitian ini adalah 1) Menganalisis besarnya tingkat pertumbuhan dan kontribusi penerimaan pajak hotel di Kota Sukabumi periode tahun 2011-2015, 2) Menganalisis besarnya efektivitas dan efisiensi pemungutan pajak hotel di Kota Sukabumi periode tahun 2011-2015, 3) Merumuskan strategi peningkatan penerimaan pajak hotel yang diselenggarakan oleh Badan Pengelolaan Keuangan Daerah (BPKD) Kota Sukabumi.

Penelitian ini diharapkan dapat memberikan manfaat bagi Dinas Pendapatan Pengelolaan Keuangan dan Aset Daerah (DPPKAD) atau Badan Pengelolaan Keuangan Daerah (BPKD) Kota Sukabumi serta pihak-pihak terkait lainnya sebagai bahan pertimbangan dan masukan dalam pengambilan kebijakan dimasa depan khususnya mengenai strategi peningkatan penerimaan pajak hotel. Kajian ini juga diharapkan dapat menumbuhkan dan menciptakan kesadaran akan arti pentingnya pajak daerah (pajak hotel) bagi masyarakat dalam pelaksanaan otonomi daerah sehingga meningkatkan PAD serta kelancaran dalam pelaksanaan pembangunan daerah di Kota Sukabumi. Juga dapat menjadi referensi bagi peneliti berikutnya yang akan mengembangkan atau melakukan penelitian sejenis.

Penelitian dilakukan di Kota Sukabumi dengan pertimbangan bahwa Kota Sukabumi merupakan kota yang strategis berdekatan dengan Kabupaten Sukabumi dan Kabupaten Bogor. Kota Sukabumi dikelilingi oleh pegunungan yang sangat menarik bagi wisatawan untuk berkunjung dan menginap di Kota Sukabumi. Dengan melihat kondisi geografis tersebut, maka diharapkan penerimaan pajak hotel di Kota Sukabumi akan meningkat. Namun data dari periode tahun 2011-2015 penerimaan pajak hotel belum maksimal, kontribusi pajak hotel terhadap pajak daerah sangat kecil karena masih dibawah $5 \%$, ini menjadi salah satu alasan mengapa lokasi penelitian ini dilakukan di Kota Sukabumi. Penelitian ini difokuskan pada strategi peningkatan penerimaan pajak hotel di Kota Sukabumi.

Dalam pelaksanaaan penelitian mengenai strategi peningkatan penerimaan pajak hotel di Kota Sukabumi, penulis merujuk beberapa penelitian terdahulu yang terkait dengan peningkatan penerimaan pajak hotel. Penelitian pertama Fahik (2009) meneliti tentang Penghitungan Potensi Pajak Hotel dan Restoran Tahun 2008 di Kabupaten Kudus. Tujuan dalam penelitian tersebut adalah untuk mengetahui kinerja penerimaan pajak hotel dan restoran, berapa besar potensi pajak hotel dan restoran, serta mengevaluasi tarif pajak yang berlaku selama ini di Kabupaten Kudus. Metode analisis yang digunakan adalah tax effort, perhitungan potensi, analisis efektivitas, analisis efisiensi, kuisioner dan deskriptif. Dari hasil perhitungan data kuisioner, di dapat total potensi pajak hotel dan restoran lebih besar dari target yang telah ada. Upaya pajak yang dilakukan Pemerintah Kabupaten Kudus masih sangat rendah dibandingkan dengan nilai tambah PDRB subsektor hotel dan restoran sedangkan tingkat efektivitas penerimaan pajak hotel dan restoran tahun 2007 adalah sangat tidak efektif.

Penelitian berikutnya Nuryani (2010) tentang Analisis Pajak Hotel di Kabupaten Badung. Penelitian tersebut bertujuan untuk menghitung dan menganalisis potensi, efektivitas, dan efisiensi dari penerimaan pajak hotel di Kabupaten Badung tahun 2008 , serta mengetahui faktor-faktor yang mempengaruhi penerimaan pajak hotel di Kabupaten Badung. Metode-metode yang digunakan yaitu analisis potensi, analisis efektivitas, analisis efisiensi, dan analisis multiple regression double log untuk mengetahui faktor-faktor yang mempengaruhi penerimaan pajak hotel. Hasil analisis menunjukkan bahwa potensi pajak hotel pada tahun 2008 adalah sebesar Rp11 265423267 058.60, tingkat efektivitas pemungutan pajak hotel tahun 2008 adalah tidak efektif dengan tingkat efektivitas sebesar 5.15\%, tingkat efisiensi pemungutan pajak hotel adalah tinggi dengan tingkat efisiensi mencapai $17.74 \%$. Variabel jumlah wisatawan mancanegara tercatat berpengaruh positif dan signifikan terhadap penerimaan pajak hotel di Kabupaten Badung, dan tingkat penerimaan pajak hotel di Kabupaten Badung "elastis" terhadap jumlah wisatawan mancanegara, dimana jika jumlah wisatawan mancanegara meningkat $1 \%$, maka tingkat penerimaan pajak hotel meningkat $2.41 \%$. Variabel Dummy Krisis Moneter tercatat berpengaruh positif dan signifikan terhadap penerimaan pajak hotel di Kabupaten Badung.

Wijayanti (2012) dalam penelitiannya tentang Analisis Kontribusi dan Proyeksi Jenis-jenis Pajak Daerah Kabupaten Ngawi. Tujuan dari penelitian adalah mengetahui pertumbuhan dan kontribusi jenisjenis pajak daerah di Kabupaten Ngawi tahun 20052010 serta proyeksi dimasa yang akan datang. Metode penelitian yang digunakan adalah analisis tingkat pertumbuhan, kontribusi, dan proyeksi. Hasil penelitian disimpulkan bahwa tren tingkat pertumbuhan tiap jenis pajak daerah mengalami fluktuatif. Jenis pajak daerah yang memberikan kontribusi besar terhadap PAD adalah Pajak 
Penerangan Jalan. Hasil proyeksi masa yang akan datang menunjukkan peningkatan tiap tahunnya, hanya pajak sarang walet yang memiliki kecenderungan menurun.

Penelitian selanjutnya Pujiasih dan Wardani (2014) tentang Analisis Potensi, Efektivitas dan Kontribusi Pajak Hotel terhadap Pendapatan Asli Daerah Kabupaten Sleman. Tujuan dari penelitian tersebut adalah menganalisis potensi pajak hotel, mengetahui besarnya efektivitas, kontribusi dari pajak hotel. Alat analisis berupa analisis potensi, efektivitas dan kontribusi. Berdasarkan hasil analisis dan pembahasan bahwa semakin meningkatnya pajak hotel di Kabupaten Sleman maka PAD yang ada juga ikut meningkat, jumlah hotel meningkat maka potensi pajak hotel juga meningkat, tetapi peningkatannya tidak setinggi peningkatan jumlah hotel yang ada.

Lengkong et al. (2016) penelitian mengenai Analisis Efektivitas Realisasi Pajak Hotel dan Kontribusinya Terhadap Pendapatan Asli Daerah pada Dinas Pendapatan Asli Daerah Kota Bitung. Tujuan penelitiannya adalah untuk mengetahui tingkat efektivitas realisasi pajak hotel dan kontribusinya terhadap PAD di Kota Bitung. Jenis data yang digunakan adalah kualitatif dan kuantitatif, sumber data yang digunakan adalah data primer dan sekunder. Metode analisis yang digunakan adalah deskriptif dan alat analisis berupa analisis efektivitas dan analisis kontribusi. Hasil penelitian menunjukkan bahwa tingkat efektivitas pajak hotel tahun 20112015 sangat efektif. Tahun 2011 merupakan tingkat efektivitas pajak hotel tertinggi, sedangkan yang terendah berada pada tahun 2012. Kontribusi pajak hotel terhadap PAD Kota Bitung tahun 2011-2015 dari tahun ke tahun selalu mengalami penurunan dengan kriteria kontribusi "sangat kurang".

Utama (2009) penelitiannya yang berjudul Strategi Peningkatan Pendapatan Asli Daerah Kabupaten Lampung Barat. Tujuan penelitian adalah mengukur kinerja keuangan pemerintah daerah Kabupaten Lampung Barat, menyusus rancangan program untuk meningkatkan PAD. Analisis yang digunakan, yaitu rasio tingkat kemandirian, rasio efektivitas, rasio efisiensi, dan rancangan program menggunakan metode AHP. Hasil analisis tingkat kemandirian tergolong sangat rendah, rasio efektivitasnya sudah efektif, dan tingkat efisiensi mengalami penurunan. Strategi yang dapat diprioritaskan dalam perancangan program melalui kegiatan pengembangan sektor unggulan, yaitu retribusi pemungutan kayu dan pajak restoran.
Sedangkan pada penelitian ini, penulis ingin mengkaji mengenai Strategi Peningkatan Penerimaan Pajak Hotel di Kota Sukabumi. Dimana Kota Sukabumi merupakan salah satu kota yang strategis karena berada pada jalur lintasan ibukota provinsi, Kota Sukabumi juga memiliki keunggulan kompetitif, selain sebagai kota yang wilayahnya berdekatan dengan Kabupaten Sukabumi yang memiliki banyak tempat wisata alam, tetapi juga berada di kaki gunung yang hawanya masih sejuk sehingga banyak menarik wisatawan yang akan memanfaatkan Kota Sukabumi sebagai tempat kegiatan bisnis/usaha, sekedar menginap dan wisata kuliner. Dengan Kedatangan wisatawan di Kota Sukabumi akan membuka peluang para investor untuk berinvestasi di bidang pariwisata seperti tempat bermain, menginap (hotel, wisma, homestay), restoran, warung, angkutan dan lain-lain yang akan berdampak pada perekonomian masyarakat lokal dan memberikan peluang bagi pemerintah Kota Sukabumi untuk menggali sumber pendapatan asli daerah dari pajak hotel. Tujuan dalam penelitian ini adalah menganalisis besarnya tingkat pertumbuhan dan kontribusi penerimaan pajak hotel, menganalisis besarnya efektivitas dan efisiensi pemungutan pajak hotel, dan merumuskan strategi kebijakan dalam meningkatkan penerimaan pajak hotel di Kota Sukabumi. Metode analisis yang digunakan dalam penelitian ini adalah analisis pertumbuhan, analisis kontribusi, analisis efektivitas, analisis efisiensi, deskriptif, dan AHP.

\section{METODE PENELITIAN}

Penelitian ini menggunakan data primer dan data sekunder yang diperoleh dari Badan Pusat Statistik (BPS) dan Badan Pengelolaan Keuangan Daerah Kota Sukabumi. Adapun sebagai objek dalam penelitan ini adalah pajak hotel di Kota Sukabumi, Jawa Barat.

Data yang digunakan terdiri dari data primer dan data sekunder. Data primer diperoleh melalui wawancara dengan pihak Pemerintah Kota Sukabumi dan observasi langsung di lapangan. Data sekunder diperoleh dari BPKD, Dinas Pariwisata dan Kebudayaan (Disparbud), Badan Pusat Statistika (BPS) Kota Sukabumi, literatur, hasil kajian dan informasi lainnya yang berhubungan dengan topik penelitian. Purposive sampling dilakukan untuk pengolahan Analitycal Hierarchy Process (AHP) dengan menetapkan responden sebanyak 5 orang yang dapat mewakili dan mengerti strategi peningkatan penerimaan pajak hotel. Metode analisis 
yang digunakan yaitu, analisis pertumbuhan. Dalam melakukan perhitungan pertumbuhan, rumus yang dapat digunakan untuk menghitung tingkat pertumbuhan pajak hotel menurut Mahmudi (2010), yaitu :

$$
P_{t}=\frac{x_{t}-x_{t-1}}{x_{t-1}} \times 100 \%
$$

Keterangan:

$\mathrm{P}_{\mathrm{t}}$ = Laju pertumbuhan pajak hotel pertahun
$\mathrm{X}_{\mathrm{t}}=$ Realisasi penerimaan pajak hotel tahun tertentu

$\mathrm{X}_{\mathrm{t}-1}=$ Realisasi penerimaan pajak hotel tahun sebelumnya

Analisis kontribusi. Dalam mengukur nilai kontribusi secara rinci digunakan kriteria kontribusi kedalam enam tingkatan. Analisis kontribusi dirumuskan sebagai berikut (Mahmudi 2010):

$$
\text { Rasio Kontribusi }=\frac{\sum \text { realisazi pajak hotel tahun tertentu }}{\sum \text { realisasi PAD tahun tertentu }} \times 100 \%
$$

Tabel 2. Klasifikasi Kriteria Kontribusi

\begin{tabular}{ll}
\hline Persentase & Kriteria \\
\hline $0-10$ & Sangat Kurang \\
$11-20$ & Kurang \\
$21-30$ & Sedang \\
$31-40$ & Cukup Baik \\
$41-50$ & Baik \\
Diatas 50 & Sangat Baik \\
\hline
\end{tabular}

Sumber: Tim Litbang Depdagri-Fisipol UGM 1991 (dalam Handoko, 2013)

Analisis efektivitas. Analisis efektivitas digunakan untuk mengukur upaya pemungutan pajak hotel yang dilakukan BPKD Kota Sukabumi. Mahmudi (2010) rumus efektivitas yang digunakan adalah :

$$
\text { Efektivitas }=\frac{\text { Reali sazi pajak hotel }}{\text { Target penerimaan pajak hotel }} \times 100 \%
$$

Tabel 3. Tabel Interpretasi Nilai Efektivitas

\begin{tabular}{ll}
\hline Persentase & Kriteria \\
\hline$>100 \%$ & Sangat Efektif \\
$90-100 \%$ & Efektif \\
$80-90 \%$ & Cukup Efektif \\
$60-80 \%$ & Kurang Efektif \\
$<60 \%$ & Tidak Efektif \\
\hline
\end{tabular}

Sumber: Mahmudi (2010)

Analisis efisiensi. Analisis efisiensi digunakan untuk mengukur perbandingan antara biaya pemungutan dan realisasi penerimaan pajak hotel pada tahun tertentu. Mahmudi (2010) rumus efisiensi yang digunakan adalah :

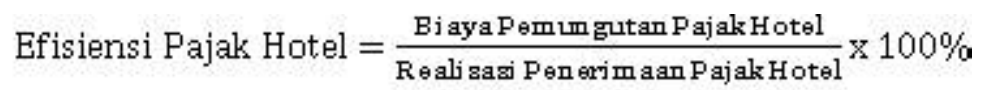

Kriteria yang dapat digunakan untuk menilai efisiensi pajak hotel sesuai dengan Tabel 4.

Analisis perumusan strategi peningkatan penerimaan pajak hotel. Analitycal Hierarchy Process (AHP) adalah sebuah hirarki fungsional dengan inputan utamanya diperoleh dari persepsi pakar. Wirdianto dan Elpira (2008), mengatakan bahwa AHP merupakan salah satu metode yang dapat digunakan dalam proses pengambilan keputusan dari suatu masalah yang kompleks seperti perencanaan, penentuan alternatif, peyusunan prioritas, pemilihan kebijakasanaan, alokasi sumber, penentuan kebutuhan, peramalan kebutuhan, perencanaan performance, optimasi dan pemecahan konflik. Prinsip kerja AHP adalah penyederhanaan suatu persoalan kompleks yang tidak terstruktur, strategis, dan dinamik menjadi sebuah bagian-bagian dan tertata dalam suatu 
Tabel 4. Kriteria Efisiensi

\begin{tabular}{cl}
\hline Prosentase & Kriteria \\
\hline$<10 \%$ & Sangat Efisien \\
$10 \%-20 \%$ & Efisien \\
$21 \%-30 \%$ & Cukup Efisien \\
$31 \%-40 \%$ & Kurang Efisien \\
$>40 \%$ & Tidak Efisien \\
\hline
\end{tabular}

Sumber: Mahmudi (2010)

hierarki. Tingkat kepentingan setiap variabel diberi nilai numerik, secara subjektif tentang arti penting variabel tersebut dan secara relatif dibandingkan dengan variabel yang lain. Setelah itu, dari berbagai pertimbangan kemudian dilakukan sintesa untuk menetapkan variabel yang memiliki prioritas tinggi dan berperan untuk mempengaruhi hasil pada sistem tersebut (Marimin \& Maghfiroh 2010).

Dalam penelitian ini digunakan alat analisis AHP untuk menentukan kriteria dan alternatif strategi peningkatan penerimaan pajak hotel. Dalam merumuskan strategi kebijakan, kuesioner dan wawancara dilakukan kepada para pejabat di Badan Pengelolaan Keuangan Daerah (BPKD) Kota Sukabumi, Dewan Perwakilan Rakyat Daerah (DPRD) Kota Sukabumi, Pengusaha perhotelan, dan Masyarakat dengan pemilihan sampel secara disengaja terhadap 5 responden. Hirarki yang disusun adalah lima level terdiri atas "Goal" yaitu prioritas strategi peningkatan penerimaan pajak hotel; empat "faktor" yaitu sistem pengelolaan, sistem pengawasan, SDM, dan kondisi perhotelan; empat "aktor" yaitu BPKD, DPRD, Pengusaha, masyarakat; empat "kendala" yaitu keterbatasan SDM, sarana dan prasarana, kurangnya promosi, kurangnya kesadaran WP; dan enam "prioritas strategi" yaitu perbaikan sistem pengelolaan penerimaan pajak, perbaikan sisten pengawasan penerimaan pajak hotel, peningkatan sarana dan prasarana (infrastruktur), peningkatan kualitas SDM, peningkatan promosi wisata, dan peningkatan sosialisasi dan penegakan hukum.

Analisis AHP dapat menghasilkan prioritas yang dapat dipilih untuk fokus terhadap tujuan meningkatkan penerimaan pajak hotel Kota Sukabumi. Prioritas yang dihasilkan dalam analisis ini akan menunjukkan strategi yang dapat dilakukan oleh pemerintah dalam peningkatan penerimaan pajak hotel untuk mendororng kemandirian daerah dan sebagai sumber-sumber pembiayaan pembangunan daerah Kota Sukabumi.

\section{HASIL DAN PEMBAHASAN}

Pemungutan pajak hotel di Kota Sukabumi menggunakan sistem self assesment yang merupakan suatu sistem pengenaan pajak yang memberikan kepercayaan kepada wajib pajak untuk menghitung, memperhitungkan, membayar dan melaporkan pajak yang terhutang dengan jumlah besaran sesuai dengan omset bulanan pemasukan dengan menggunakan Surat Pemberitahuan Pajak Daerah (SPTPD). Dalam hal ini pajak hotel dibayarkan oleh wajib pajak setelah terlebih dahulu ditetapkan oleh Kepala Daerah atau pejabat yang di tunjuk. Dimana wewenang dalam menentukan besarnya pajak terutang ada pada wajib pajak sendiri. Wajib pajak harus aktif dengan mulai menghitung, menyetor, dan melaporkan sendiri pajak yang terutang. Untuk Fiskus/petugas pemungut pajak tidak dapat ikut campur karena tugasnya hanya sekedar mengawasi.

Pemungutan pajak dengan sistem self assessment diperlukan kejujuran dan kesadaran yang sangat besar dari wajib pajak dalam menentukan dan membayarkan pajaknya karena akan mempengaruhi besarnya penerimaan pajak hotel. Disinilah peranan aktif yang harus dilakukan oleh BPKD dalam rangka menghimpun penerimaan pajak hotel dengan cara melakukan pengelolaan dan pengawasan secara baik dan benar, serta menyadarkan wajib pajak akan arti pentingnya pajak dalam pembangunan daerah, sehingga akan memberikan dampak yang positif bagi kepatuhan wajib pajak hotel dan penerimaan dari pajak hotel.

Pemerintah Kota Sukabumi melakukan pemungutan pada 5 jenis klasifikasi hotel yaitu hotel bintang tiga, melati tiga, melati dua, melati satu, dan non melati. Klasifikasi hotel tersebut menjadi pendongkrak pajak hotel yang ada di Kota Sukabumi, sehingga dengan begitu pertumbuhan, kontribusi, efektivitas, dan efisiensi dari pajak hotel tersebut perlu diketahui guna mengukur kinerja pemungutan penerimaan dari pajak hotel di Kota Sukabumi.

Perkembangan hotel dan penginapan di Kota Sukabumi berdasarkan data BPS (2016) dapat dilihat pada Tabel 5. Pada tahun 2014 sampai dengan tahun 2016 mengalami fluktuatif, tetapi jumlah kamar, jumlah tempat tidur, dan jumlah rata-rata pengunjung hotel tiap harinya meningkat pesat. Tahun 2014 
jumlah hotel sebanyak 32, 759 kamar, 1120 tempat tidur, dan 295 orang rata-rata per hari. Tahun 2015 jumlah hotel turun menjadi sebanyak 30 , tetapi terjadi kenaikan pada jumlah kamar, tempat tidur, rata-rata tamu perhari berturut-turut sebanyak 876 kamar, 1278 tempat tidur, dan 394 orang. Pada tahun 2016 naik sebanyak 33 hotel, 987 kamar, 1426 tempat tidur, dan 453 orang rata-rata perhari. Dimana sebanyak
33 hotel terdiri dari 2 hotel bintang tiga, 12 hotel melati tiga, 9 hotel melati dua, dan 10 hotel melati satu yang tersebar di tiga Kecamatan yaitu Kecamatan Cikole, Waru Doyong, dan Gunung Puyuh. Dengan adanya peningkatan tersebut secara otomatis akan meningkatkan jumlah penerimaan pajak hotel di Kota Sukabumi.

Tabel 5. Jumlah hotel, kamar hotel, dan rata-rata tamu perhari tahun 2014-2016

\begin{tabular}{lcccccc}
\hline \multirow{2}{*}{ Tahun } & \multicolumn{3}{c}{ Banyaknya } & \multicolumn{2}{c}{ Rata-rata tamu per hari } \\
\cline { 2 - 7 } & Usaha & Kamar & Tempat Tidur & Indonesia & Asing & Total \\
\hline 2014 & 32 & 759 & 1120 & 295 & - & 295 \\
2015 & 30 & 876 & 1278 & 390 & 4 & 394 \\
2016 & 33 & 987 & 1426 & 447 & 6 & 453 \\
\hline
\end{tabular}

Sumber : Badan Pusat Statistik Propinsi Jawa Barat (2016)

Analisis pertumbuhan dan kontribusi digunakan untuk mengetahui kinerja dari penerimaan pajak hotel sesuai dengan pendapat Juri (2012), mengatakan bahwa data dalam menghitung tingkat pertumbuhan suatu pajak daerah berdasarkan dari berapa target yang ditentukan pada tahun tertentu dan berapa jumlah realisasi yang didapat pada tahun tertentu juga. Analisis pertumbuhan menggambarkan perkembangan penerimaan pajak dari tahun ke tahun (Yuliani et al. 2015). Mustika (2014), mengatakan bahwa pertumbuhan merupakan sesuatu yang dapat mengalami kenaikan maupun penurunan dalam suatu penerimaan. Hasil analisis pertumbuhan penerimaan pajak hotel dapat dilihat pada Tabel 7. Realisasi penerimaan pajak hotel tahun 2011-2013 meningkat, pada tahun 2014 mengalami penurunan, dan pada tahun 2015 meningkat signifikan. Pertumbuhan pajak hotel cenderung fluktuatif, mengalami penurunan tahun 2012-2014. Pada tahun 2015 pertumbuhan positif yang cukup signifikan. Rata-rata pertumbuhan realisasi pajak hotel pada tahun 20112015 sebesar $13.18 \%$.

Berdasarkan Gambar 2 menunjukkan bahwa pertumbuhan jenis pajak hotel mengalami naik-turun, laju pertumbuhan dari penerimaan pajak hotel yang terjadi pada kelima jenis pajak hotel yang mengalami pertumbuhan negatif terjadi pada tahun 2014, berarti bahwa pada tahun tersebut pertumbuhan dari keseluruhan jenis pajak hotel mengalami perlambatan dan kondisi yang tidak baik/buruk. Hotel bintang tiga dari tahun 2012 sampai dengan tahun 2014 mengalami penurunan. Pada tahun 2015 mengalami kenaikan yang cukup signifikan sebesar 83\%. Pajak hotel melati tiga mengalami pertumbuhan yang menurun sekali hingga mencapai minus dari tahun 2011 sampai tahun 2014. Hotel melati 3 pada tahun 2015 tidak mengalami pertumbuhan sama sekali yaitu sebesar 0\%. Pajak hotel melati dua mengalami pertumbuhan yang fluktuatif, dimana tahun 2012 pertumbuhan menurun hingga sebesar $1 \%$, pertumbuhan naik di tahun 2013 sebesar 5\%, turun drastis hingga $-31 \%$ di tahun 2014 , dan mengalami pertumbuhan yang cukup baik pada tahun 2015. Pajak hotel melati satu terjadi hal yang sama dimana pertumbuhan naik-turun dari tahun 2012 sebesar -30\%, tahun 2013 naik kemudian turun kembali menjadi $-25 \%$ pada tahun 2014, dan mengalami kenaikan di tahun 2015. Pertumbuhan pajak hotel non melati yang tidak mengalami pertumbuhan pada tahun 2012 dan 2013 yaitu sebesar $0 \%$, mengalami penuruhan pertumbuhannya dari tahun 2014-2015 dikarenakan pada pertengahan tahun 2014 satu-satunya hotel non melati di Kota Sukabumi tutup yaitu Hotel Resik.

Besar tingkat kontribusi dari masing-masing jenis pajak hotel terhadap total realisasi pajak daerah dan terhadap Pendapatan Asli Daerah (PAD) dapat dilakukan dengan melakukan perhitungan terhadap realisasi pajak hotel yang dibandingkan dengan total realisasi pajak daerah atau PAD dan dikalikan dengan $100 \%$ (seratus persen). Kontribusi setiap pajak hotel akan membawa pengaruh terhadap total pendapatan pajak daerah dan pada akhirnya akan mempengaruhi terhadap total pendapatan asli daerah. Fery dan Devianty (2013), melakukan analisis kontribusi untuk dapat mengetahui berapa besar kontribusi yang diberikan oleh sektor pajak daerah dibandingkan dengan sektor lainnya yang 


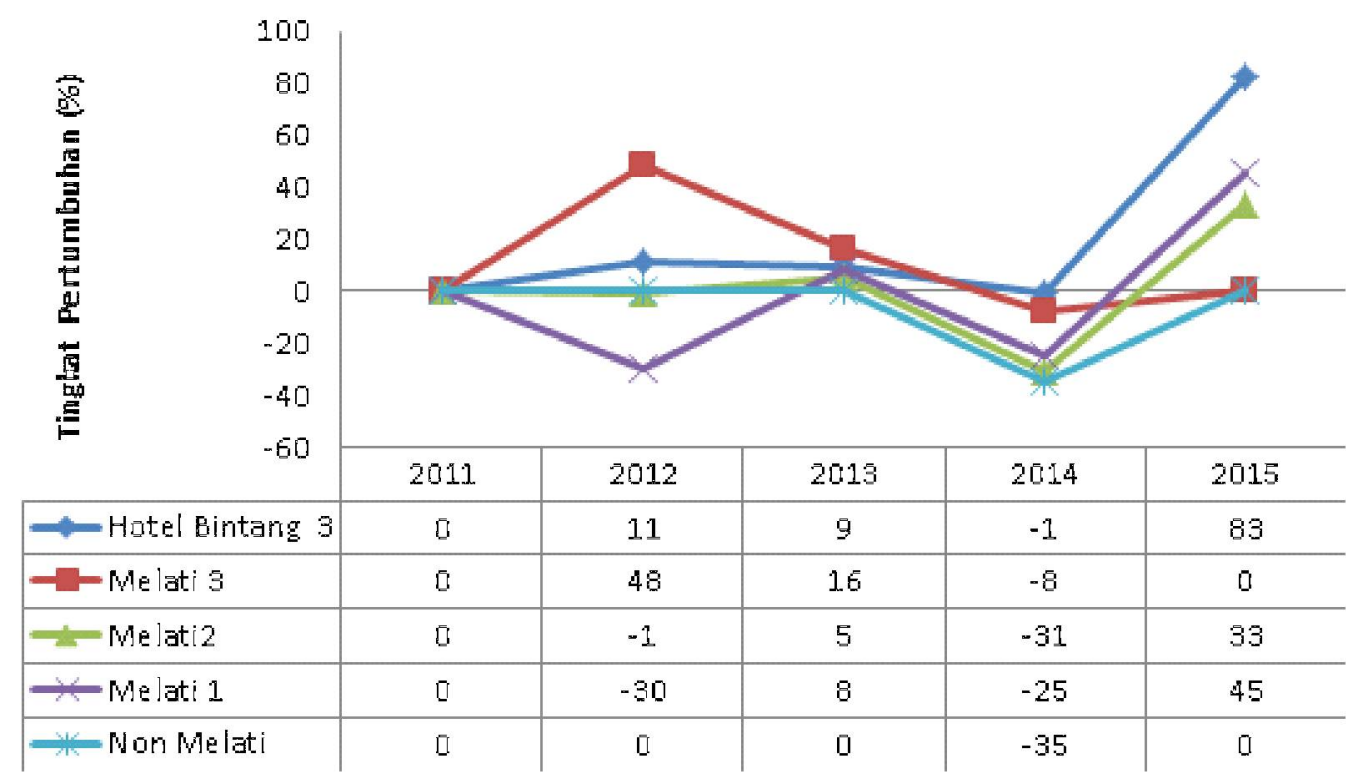

Gambar 2. Pertumbuhan Penerimaan Pajak Hotel Berdasarkan Klasifikasi Hotel di Kota Sukabumi Tahun 2011-2015

Sumber: Data diolah (2017)

Tabel 6. Pertumbuhan Pajak Hotel di Kota Sukabumi Tahun 2011-2015

\begin{tabular}{lcc}
\hline Tahun & Realisasi pajak hotel (rupiah) & Pertumbuhan pajak hotel $(\%)$ \\
\hline 2011 & 678266435 & - \\
2012 & 797747655 & 17.62 \\
2013 & 892668862 & 11.90 \\
2014 & 803444145 & $(10)$ \\
2015 & 1070034811 & 33.18 \\
\hline \multicolumn{2}{c}{ Rata-rata pertumbuhan pajak hotel } & 13.18 \\
\hline
\end{tabular}

Sumber: Data diolah (2017)

diakibatkan karena belum maksimalnya unsur-unsur pajak daerah yang telah dipungut. Berikutnya untuk mengetahui besarnya kontribusi dari penerimaan pajak hotel terhadap total realisasi pajak daerah dan
PAD dapat dilihat pada Tabel 7. Kontribusi pajak hotel akan berpengaruh terhadap total pendapatan pajak daerah dan total pendapatan asli daerah (PAD).

Tabel 7. Kontribusi Pajak Hotel terhadap Pajak Daerah dan PAD di Kota Sukabumi Tahun 2011-2015

\begin{tabular}{cccccc}
\hline Tahun & $\begin{array}{c}\text { Pajak Hotel } \\
\text { (juta rupiah) }\end{array}$ & $\begin{array}{c}\text { Pajak Daerah } \\
\text { (juta rupiah) }\end{array}$ & $\begin{array}{c}\text { Kontribusi } \\
\text { terhadap Pajak } \\
\text { Daerah }(\%)\end{array}$ & $\begin{array}{c}\text { Kontribusi } \\
\text { terhadap } \\
\text { PAD }(\%)\end{array}$ & Kriteria \\
\hline 2011 & 678.27 & 15222.70 & 4.46 & 0.59 & Sangat Kurang \\
2012 & 797.75 & 17886.46 & 4.46 & 0.54 & Sangat Kurang \\
2013 & 892.67 & 21156.64 & 4.22 & 0.51 & Sangat Kurang \\
2014 & 803.44 & 28399.45 & 2.83 & 0.31 & Sangat Kurang \\
2015 & 1070.03 & 29688.55 & 3.60 & 0.39 & Sangat Kurang \\
\hline \multicolumn{2}{r}{ Rata-rata kontribusi pajak hotel } & 3.91 & 0.47 & Sangat Kurang \\
\hline
\end{tabular}

Sumber: Data diolah (2017) 
Berdasarkan Tabel 7 terlihat bahwa kontribusi pajak hotel terhadap pajak daerah dan PAD ratarata dari tahun 2011-2015 sebesar 3.91\% dan 0.47 $\%$. Penerimaan pajak meningkat tiap tahunnya, tetapi tingkat kontribusi yang dihasilkan sangat kecil cenderung menurun dan berada pada kategori sangat kurang. Rendahnya kontribusi pajak hotel terhadap pajak daerah dan PAD disebabkan karena kenaikan pajak hotel yang tidak sebesar kenaikan pajak daerah yang lainnya. Hal tersebut menjadi tantangan bagi BPKD Kota Sukabumi dalam mengoptimalkan penggalian potensi dari pajak hotel dan meningkatkan pengawasan dalam pelaksanaan penerimaan pajak hotel.

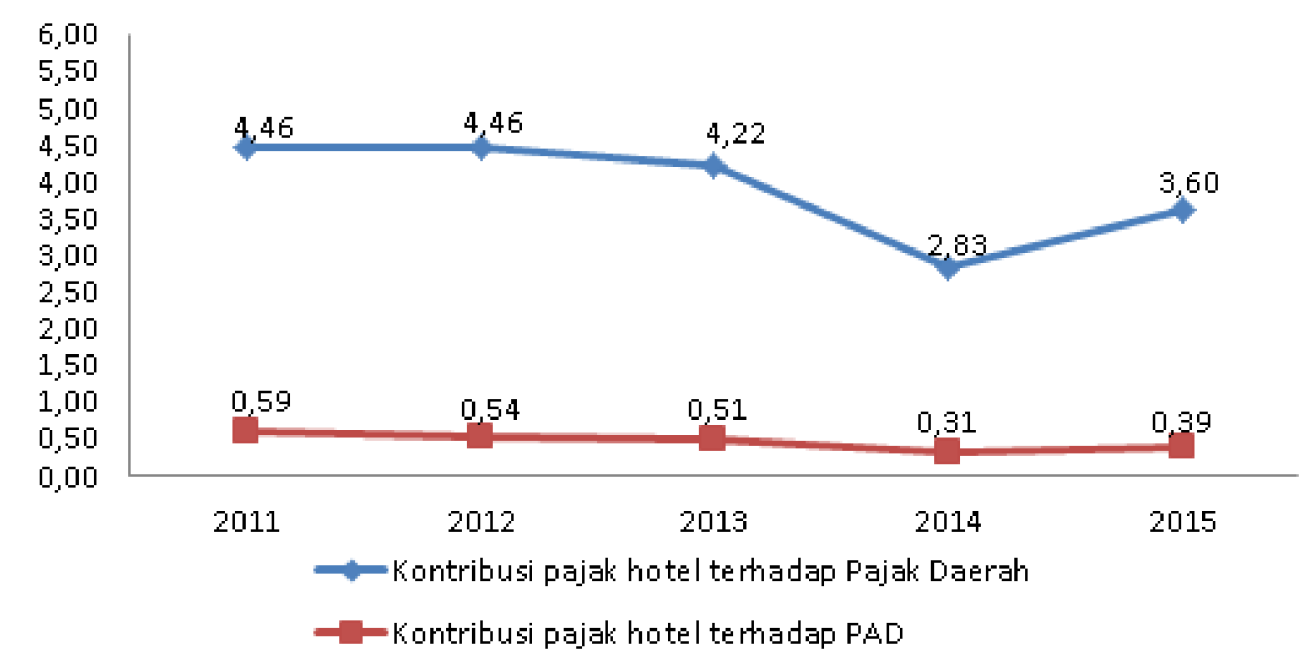

Gambar 3. Grafik Kontribusi Pajak Hotel terhadap Pajak Daerah dan PAD Sumber : Data diolah (2017)

Berdasarkan Gambar 3 menunjukkan bahwa perbandingan kontribusi pajak hotel terhadap pajak daerah dan pendapatan asli daerah, dimana dari kedua kontribusi tersebut tren yang ada menunjukkan penurunan dari tahun 2011-2014. Pada tahun 2015 kontribusi terhadap pajak daerah dan PAD yang mengalami kenaikan. Tingkat kontribusi pajak hotel terhadap pajak daerah dan PAD Kota Sukabumi dari tahun ke tahun mengalami penurunan yaitu dari tahun 2011-2015 dengan kriteria kontribusi "sangat kurang". Terlihat bahwa tiap tahun penerimaan pajak hotel sangat baik tetapi tetap mengalami fluktuatif. Pajak hotel dalam kontribusinya terhadap pendapatan asli daerah rata-rata terus mengalami penurunan di setiap tahunnya. Kontribusi pajak hotel mengalami penurunan karena total Pendapatan Asli Daerah (PAD) Kota Sukabumi dalam setiap tahunnya mengalami peningkatan. Walaupun penerimaan pajak hotel di setiap tahunnya mengalami peningkatan tetapi total PAD Kota Sukabumi juga meningkat seiring meningkatnya jumlah penerimaan dari jenis pajak daerah yang lain, retribusi daerah, dan pendapatan asli daerah yang lainnya.

Badan Pengelolaan Keuangan Daerah (BPKD) Kota Sukabumi melaksanakan pemungutan pajak hotel sudah sesuai dengan ketetapan undang-undang dan peraturan yang berlaku. Pajak hotel adalah pajak yang dikenakan atas fasilitas yang diberikan oleh hotel, sedangkan efektivitas merupakan suatu alat sebagai indikator dalam mengukur sejauh mana usaha pungut yang telah dilakukan, untuk mengukur hubungan antara hasil pungutan dengan tujuan atau target yang telah di tetapkan. Menurut Octovido (2014), pada penelitian yang telah dilakukan melakukan perhitungan tingkat efektivitas untuk mengetahui seberapa besar tingkat efektivitas pada setiap tahunnya dari realisasi dan target dari penerimaan pajak daerah sehingga dapat diketahui kinerja dari pihak yang melakukan pemungutan pajak daerah tersebut. Untuk mengetahui tingkat efektivitas pemungutan pajak hotel Kota Sukabumi dapat dilihat pada Tabel 8 .

Pada Tabel 8 menunjukkan bahwa, tingkat efektivitas pemungutan pajak hotel pada tahun 20112015 rata-rata sangat efektif dengan realisasi hampir seluruhnya mencapai diatas $100 \%$ yaitu rata-rata sebesar $107.93 \%$, walaupun pada tahun 2014 efektivitas pemungutan pajak hotel masih dibawah $100 \%$ yaitu sebesar $95.55 \%$. Pada 2014 tidak tercapai target penerimaannya dikarenakan masih ada beberapa wajib pajak hotel yang belum membayar tunggakan pajaknya. Sejalan dengan hasil penelitian Lengkong et al (2016) dimana hasil efektivitas dari tahun ke tahun mengalami naik turun, karena tidak terlepas dari adanya masalah-masalah selama penerimaan pajak hotel yang salah satunya karena kurangnya kesadaran wajib pajak dalam membayar 
Tabel 8. Tingkat Efektivitas Pajak Hotel di Kota Sukabumi Tahun 2011-2015

\begin{tabular}{ccccc}
\hline Tahun & $\begin{array}{c}\text { Target } \\
\text { (juta rupiah) }\end{array}$ & $\begin{array}{c}\text { Realisasi } \\
\text { (juta rupiah) }\end{array}$ & $\begin{array}{c}\text { Efektivitas } \\
(\%)\end{array}$ & Kategori \\
\hline 2011 & 577.6 & 678.3 & 117.43 & Sangat Efektif \\
2012 & 728.5 & 797.7 & 109.50 & Sangat Efektif \\
2013 & 818.3 & 892.7 & 109.09 & Sangat Efektif \\
2014 & 840.8 & 803.4 & 95.55 & Efektif \\
2015 & 990.3 & 1070.0 & 108.05 & Sangat Efektif \\
\hline \multicolumn{5}{c}{ Rata-rata persentase } \\
\hline
\end{tabular}

Sumber: Data diolah (2017)

pajak. Namun performa kinerja pemerintah dalam hal ini BPKD Kota Sukabumi sudah baik, dimana tingkat efektivitas dalam pelaksanaan pemungutan pajak hotel dalam kurun waktu 5 tahun hampir termasuk dalam kategori "sangat efektif".

Menurut Fahik (2009) bahwa tingkat efisiensi menunjukkan seberapa besar bagian dari penerimaan suatu pungutan yang digunakan untuk menutup seluruh biaya yang dikeluarkan dalam melaksanakan pungutan tersebut, Efisiensi dikatakan semakin tinggi apabila persentase biaya yang dikeluarkan untuk menghasilkan penerimaan suatu pungutan dapat ditekan sekecil mungkin.

Untuk mengetahui tingkat efisiensi penerimaan pajak hotel di Kota Sukabumi dapat dilakukan dengan membandingkan antara biaya pemungutan pajak hotel yang telah dikeluarkan oleh BPKD Kota Sukabumi terhadap realisasi penerimaan pajak hotel yang telah dicapai, sejalan dengan pendapat Enggar et al. (2011) yang mengatakan bahwa efisiensi merupakan suatu perbandingan antara realisasi penerimaan dari suatu pajak daerah atau hasil pajak daerah dengan jumlah total dari biaya pemungutan pajak daerah yang dikeluarkan untuk memperoleh hasil pajak daerah tersebut pertahun dalam satuan persentase. Efektif dan tidaknya aktivitas dalam pemungutan pajak hotel tergantung kepada para fiskus (pemungut pajak) dan peran pemerintah daerah (Pujiasih \& Wardani, 2014).

Analisis tingkat efisiensi dalam menentukan biaya operasional sangat sulit dilakukan oleh BPKD Kota Sukabumi, karena biaya operasional tersebut tidak hanya dikeluarkan untuk pemungutan pajak hotel, melainkan untuk pemungutan pajak-pajak yang lainnya. Sesuai dengan penelitian Yunanto (2010) bahwa dalam pengeluaran biaya tersebut bersifat biaya bersama (joint cost) sehingga dalam menentukan biaya pemungutan pajak hotel dilakukan perhitungan berdasarkan biaya-biaya yang sebenarnya dikeluarkan yaitu biaya cetak Surat Ketetapan Pajak Daerah (SKPD) dan biaya transportasi untuk menyampaikan SKPD yang dalam besarannya tiap tahun mengalami penyesuaian. Untuk mengetahui biaya pemungutan pajak hotel maka dapat dilihat pada Tabel 9.

\section{Tabel 9. Jenis dan Jumlah Biaya Pungut Pajak Hotel di Kota Sukabumi Tahun 2011-2015 (juta rupiah)}

\begin{tabular}{cccccc}
\hline Tahun & $\begin{array}{c}\text { Upah } \\
\text { Pungut }\end{array}$ & \multicolumn{2}{c}{ Biaya Operasional } & Jumlah Biaya & $\begin{array}{c}\text { Pertumbuhan } \\
(\%)\end{array}$ \\
\cline { 3 - 4 } & & $\begin{array}{c}\text { Biaya Cetak } \\
\text { SKPD }\end{array}$ & $\begin{array}{c}\text { Biaya } \\
\text { Transportasi }\end{array}$ & & \\
\hline 2011 & 33.91 & 4.00 & 1.40 & 39.31 & - \\
2012 & 39.89 & 4.00 & 3.52 & 47.40 & 20.59 \\
2013 & 44.63 & 4.00 & 1.88 & 50.51 & 6.55 \\
2014 & 40.17 & 3.00 & 1.50 & 44.67 & $(11.56)$ \\
2015 & 53.50 & 2.00 & 2.00 & 57.50 & 28.72 \\
\hline
\end{tabular}

Sumber: Data diolah (2017)

Tabel 9 menunjukkan bahwa jumlah biaya yang terdiri dari upah pungut, dan biaya operasional yang mencakup biaya cetak SKPD dan biaya transportasi besarannya tiap tahun mengalami peningkatan, hanya di tahun 2014 mengalami penurunan. Tingkat pertumbuhan jumlah biaya cukup baik karena masih positif walaupun pada tahun 2013 turun menjadi 6.55\% hingga pada tahun 2014 turun tajam menjadi negatif sebesar $-11.56 \%$. Besaran upah pungut pajak hotel juga ditentukan berdasarkan realisasi penerimaan pajak hotel sebesar 5\% sehingga tiap tahun besarnya berbeda-beda. 
Tabel 10. Tingkat Efisiensi Pajak Hotel di Kota Sukabumi Tahun 2011-2015

\begin{tabular}{ccccc}
\hline Tahun & $\begin{array}{c}\text { Realisasi } \\
\text { (juta rupiah) }\end{array}$ & $\begin{array}{c}\text { Biaya Pungut } \\
\text { (juta rupiah) }\end{array}$ & $\begin{array}{c}\text { Efisiensi } \\
(\%)\end{array}$ & Kategori \\
\hline 2011 & 678.3 & 39.31 & 5.80 & Sangat Efisien \\
2012 & 797.7 & 47.40 & 5.94 & Sangat Efisien \\
2013 & 892.7 & 50.51 & 5.66 & Sangat Efisien \\
2014 & 803.4 & 44.67 & 5.56 & Sangat Efisien \\
2015 & 1070.0 & 57.50 & 5.37 & Sangat Efisien \\
& Rata-rata tingkat efisiensi & & 5.67 & Sangat Efisien \\
\hline
\end{tabular}

Sumber: Data diolah (2017)

Berdasarkan Tabel 10 bahwa biaya pungut pada penerimaan pajak hotel besarnya fluktuatif setiap tahun. Jumlah biaya pungut yang terdiri dari upah pungut, dan biaya operasional yang mencakup biaya cetak Surat Ketetapan Pajak Daerah (SKPD) dan biaya transportasi dengan besaran tiap tahun mengalami peningkatan, hanya di tahun 2014 yang mengalami penurunan. berasal dari Rasio efisiensi paling tinggi terjadi pada tahun 2012 dan paling rendah dicapai pada tahun 2015. Rasio efisiensi pemungutan pajak hotel di Kota Sukabumi dari tahun 2011-2015 rata-rata mencapai sebesar 5.67\% artinya bahwa, dalam setiap penerimaan pajak hotel yang diperoleh sebesar seratus rupiah memerlukan biaya pemungutan sebesar 5.67 rupiah, sehingga masuk pada kategori kinerja pemungutan pajak hotel yang sangat efisien.

Dalam menentukan strategi peningkatan penerimaan pajak hotel di kota Sukabumi menggunakan pengolahan Analitycal Hierarchy Process (AHP). Hasil penyusunan bobot prioritas dari pengolahan kuesioner AHP pada level faktor yang berpengaruh pada peningkatan penerimaan pajak hotel di Kota Sukabumi berturut-turut adalah sistem pengelolaan sebesar 0.524 , sistem pengawasan bobot sebesar 0.172, kondisi perhotelan sebesar 0.163, dan SDM sebesar 0.141. Sistem pengelolaan dinilai sebagai prioritas pertama dibandingkan dengan faktor lain, karena sistem pengelolaan merupakan kunci utama keberhasilan dalam penerimaan pajak hotel. Untuk level aktor diperoleh hasil dengan urutan prioritas berturut-turut adalah BPKD dengan bobot sebesar 0.466, DPRD sebesar 0.204 , masyarakat sebesar 0.169 , dan terakhir pengusaha sebesar 0.161. BPKD menjadi prioritas pertama karena BPKD merupakan pihak yang berwewenang untuk merumuskan kebijakan dalam peningkatan penerimaan pajak hotel.

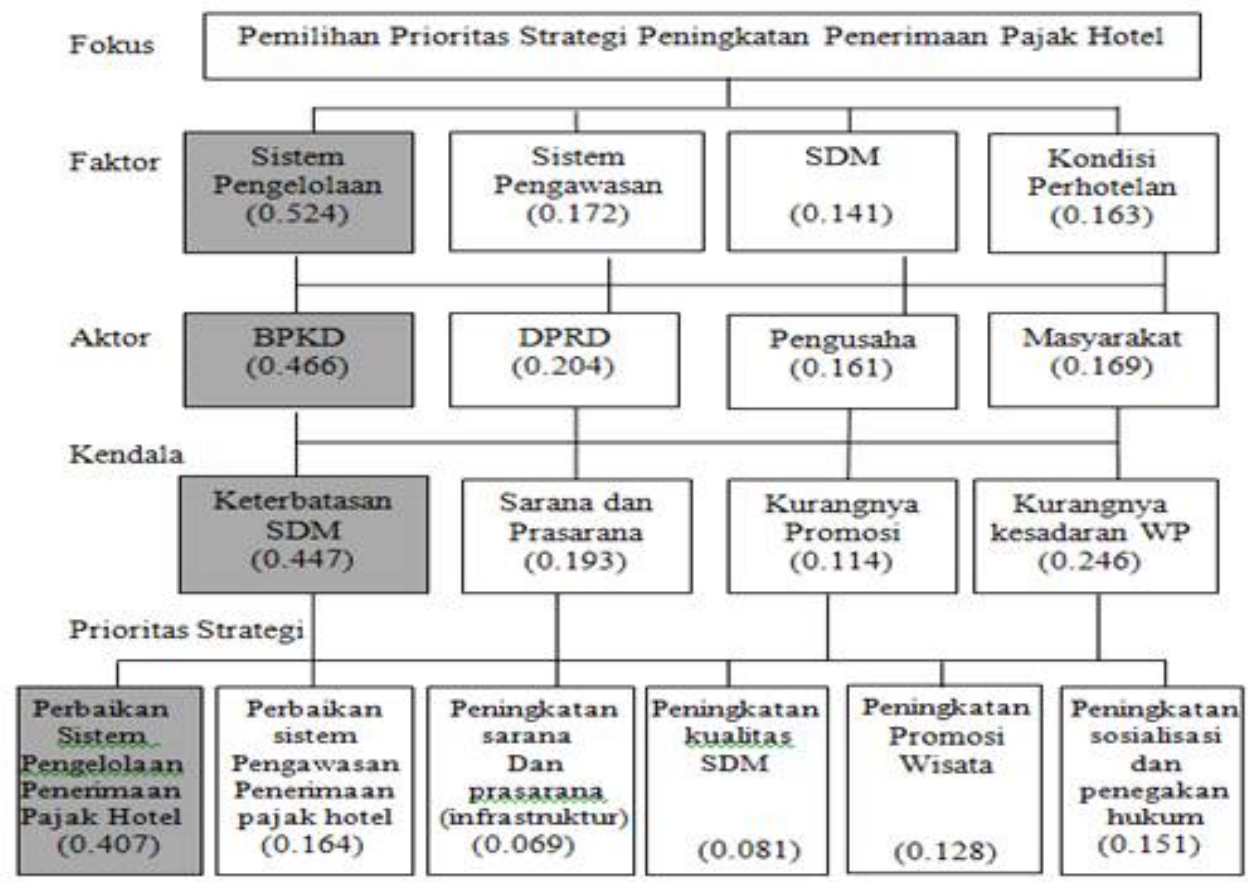

Gambar 4. Struktur dan nilai bobot hirarki strategi peningkatan penerimaan pajak hotel Kota Sukabumi 
Dalam level kendala diperoleh hasil dengan urutan prioritas berturut-tururt adalah keterbatasan SDM dengan bobot sebesar 0.447 , kurangnya kesadaran WP bobot sebesar 0.246, sarana dan prasarana dengan bobot sebesar 0.193, dan terahir kurangnya promosi sebesar 0.114 . keterbatasan SDM menjadi kendala dalam peningkatan penerimaan pajak hotel karena sistem pemungutan "self assesment" yang berlaku dimana WP sendirilah yang menentukan besaran pajaknya sehingga pemerintah hanya melakukan pengelolaan dan pengawasan, yang menjadi kendala adalah keterbatasan SDM dalam proses tersebut. Level berikutnya yaitu prioritas strategi dalam peningkatan penerimaan pajak hotel yang tertinggi adalah perbaikan sistem pengelolaan penerimaan pajak hotel sebesar 0.407. Prioritas yang kedua adalah peningkatan sistem pengawasan sebesar penerimaan pajak hotel sebesar 0.164 , prioritas selanjutnya yaitu peningkatan sosialisasi dan penegakan hukum dengan bobot sebasar 0.151, disusul dengan alternatif prioritas peningkatan promosi wisata dan peningkatan kualitas SDM masing-masing sebesar 0.128 dan 0.081 Alternatif prioritas yang terakhir nilai bobotnya sebesar 0.069 adalah peningkatan sarana dan prasarana (infrastruktur). Prioritas tertinggi dipilih strategi perbaikan sistem pengelolaan penerimaan pajak hotel karena hal tersebut menjadi kunci utama dalam peningkatan penerimaan pajak hotel. Struktur prioritas dari masing-masing level secara lengkap dapat dilihat pada Gambar 4.

Penentuan prioritas strategi yang diperoleh dari pengolahan AHP menunjukkan bahwa perbaikan sistem pengelolaan penerimaan pajak hotel mencapai bobot tertinggi yaitu sebesar 0.407 atau $40.7 \%$. Selanjutnya disusun beberapa kebijakan dalam memberikan arahan pada program dan kegiatan yang akan dilakukan oleh BPKD Kota Sukabumi.

\section{Implikasi Kebijakan}

Berdasarkan hasil analisis dan pendapat responden ahli, dalam rangka meningkatkan penerimaan pajak hotel maka alternatif strategi utama yang harus dilakukan adalah perbaikan sistem pengelolaan penerimaan pajak hotel sebagai langkah awal untuk meningkatkan penerimaan pajak hotel di Kota Sukabumi. Sejak awal adanya BPKD dimana sebelumnya memiliki nama Dinas Pendapatan Pengelolaan Keuangan dan Aset Daerah (DPPKAD) dimata masyarakat adalah tempat membayar pajak, seluruh proses transaksi keuangan ada disana, tetapi dengan berjalannya waktu dimana pemerintah Kota Sukabumi telah melakukan perubahan sistem pengelolaan sehingga yang saat ini harus dilakukan adalah melaksanakan program perbaikan sistem pengelolaan administrasi pajak terpadu berbasis komputerisasi, digitalisasi, dan online dengan beberapa kegiatan yaitu melaksanakan migrasi data dari manual ke sistem administrasi perpajakan terpadu berbasis komputerisasi, digitalisasi, dan online; sistem pembayaran online; pengadaan sistem monitoring pajak hotel (tapping box); mengoperasikan contact center pusat layanan informasi dan pengaduan pajak "Kring Pajak Kota Sukabumi".

Prioritas strategi yang kedua adalah perbaikan sistem pengawasan penerimaan pajak hotel, dimana pengawasan yang saat ini dilakukan terhadap wajib pajak dan pemungut pajak (Fiskus) hanya terkait dengan wajib pajak dan pemungut pajak yang tidak patuh, dengan perbaikan sistem dalam pengawasan ini berlaku untuk seluruhnya baik yang patuh maupun yang tidak patuh dengan sistem yang ada diperbaiki dan dilakukan penyempurnaan. Membuat whistleblowing system, peningkatan sistem pemeriksaan, pengendalian, dan pengawasan melalui kerjasama dengan instansi terkait yang lebih independen seperti perbankan dalam pengawasan transaksi WP dan Fiskus, tukar informasi dengan Kantor Pelayanan Pajak (KPP) Pratama Sukabumi terkait potensi pajak serta kewajiban perpajakannya, Inspektorat Daerah dan Komisi Pemberantasan Korupsi (KPK) terkait dugaan penyalahgunaan wewenang, suap, korupsi, kolusi, dan nepotisme.

Prioritas strategi yang selanjutnya adalah peningkatan sosialisasi dan penegakan hukum, dimana saat ini masih sedikit sekali sosialisasi terkait perpajakan dengan memberikan penyuluhan secara rutin dan terstruktur terhadap masyarakat pada umumnya dan khususnya kepada Wajib Pajak Hotel yang telah terdaftar maupun yang belum terdaftar. Dalam penegakan hukum terhadap WP dan Fiskus saat ini belum terlalu kuat sehingga harus adanya perbaikan regulasi yang jelas dan tepat guna untuk membuat efek jera bagi para WP yang tidak patuh dan Fiskus yang tidak sesuai dengan tugas dan tanggungjawabnya sehingga dapat ditindak sesuai dengan aturan dan perundang-undangan yang berlaku. Dalam pelaksanaannya BPKD Kota Sukabumi dapat bekerjasama secara tertulis dengan pihak terkait seperti Kejaksaan dan Kepolisian.

Alternatif strategi dengan urutan ke empat, yaitu kebijakan dalam peningkatan promosi wisata, dimana sampai saat ini promosi tersebut belum rutin dilakukan. Menurut Sahroni et al. (2015), 
peningkatan penerimaan pajak daerah dapat dilakukan melalui media promosi video interaktif sehingga dapat meningkatkan pemahaman tentang pajak dan kesadaran masyarakat untuk membayar pajak. Pemerintah dapat melakukan kegiatan yang dapat menarik wisatawan domestik dan wisatawan asing untuk dapat berkunjung ke Kota Sukabumi dimulai dengan hal-hal kecil, yaitu mengaktifkan kembali website Dinas Pariwisata dan Kebudayaan yang sampai sekarang belum ada pembaharuan, melakukan kerjasama dengan pihak swasta dalam mempromosikan melalui media baik online maupun offline, aktif dalam pameran seni dan budaya, memberikan diskon pemasangan reklame bagi WP hotel yang mempromosikan hotelnya, mengadakan pertemuan (BPKD dan pengusaha perhotelan) membahas cara meningkatkan jumlah pengunjung hotel.

Prioritas selanjutnya adalah peningkatan kualitas SDM dengan melakukan studi banding ke kota/ kabupaten yang lebih maju dalam hal penerimaan pendapatan asli daerahnya terutama pajak hotel, mengikuti seminar pariwisata dan perhotelan, bekerjasama dengan Balai Diklat Keuangan (BDK) untuk peningkatan keahlian dalam menghadapi WP, cara perhitungan dan penggalian potensi pajak hotel, dan memberikan reward bagi pegawai yang memiliki kinerja terbaik, dan bagi WP yang terbaik, serta memberikan punishement bagi pegawai yang melakukan pelanggaran kode etik yang telah ada dan WP yang tidak patuh.

Strategi kebijakan yang terakhir adalah peningkatan sarana dan prasarana (infrastruktur) dengan perbaikan secara berjenjang jalan yang rusak, peningkatan akses menuju objek wisata, dan perbaikan fasilitas umum. Hal tersebut akan menjadi daya tarik masyarakat luar untuk menginap di hotel dan penginapan yang ada di Kota Sukabumi. Secara langsung akan memberikan dampak positif bagi penerimaan pajak daerah khususnya pajak hotel di Kota Sukabumi.

\section{SIMPULAN DAN SARAN}

Berdasarkan hasil dan pembahasan yang telah disajikan sebelumnya, maka dapat disimpulkan bahwa besarnya tingkat pertumbuhan pajak hotel pada tahun 2011-2015 mengalami fluktuatif, dimana pertumbuhan positif meskipun semakin menurun nilainya pada tahun 2012,2013 , dan 2015 , tetapi pada tahun 2014 mengalami pertumbuhan negatif. Tingkat kontribusi pajak hotel terhadap pajak daerah dan PAD juga mengalami penurunan pada setiap tahun, besarnya kontribusi sangat kecil dan masuk kategori "sangat kurang". Tingkat efektivitas pemungutan pajak hotel pada tahun 2011-2015 rata-rata sangat efektif, hanya pada tahun 2014 realisasi penerimaan pajak hotel dibawah target yang ditetapkan, masuk kategori "efektif". Tingkat efisiensi pemungutan pajak hotel masuk kategori "sangat efisien" pada tahun 2011-2015. Strategi peningkatan penerimaan pajak hotel di Kota Sukabumi berdasarkan hasil analisis AHP sesuai urutan prioritasnya yaitu: (a) perbaikan sistem pengelolaan penerimaan pajak hotel, (b) perbaikan sistem pengawasan penerimaan pajak hotel, (c) peningkatan sosialisasi dan penegakan hukum, (d) peningkatan promosi wisata, (e) peningkatan kualitas SDM, dan (f) peningkatan sarana dan prasarana (infrastruktur).

Beberapa hal yang dapat disampaikan sebagai saran antara lain: (1) Badan Pengelolaan Keuangan Daerah (BPKD) Kota Sukabumi diharapkan untuk meningkatkan penerimaan pajak hotel yang sejalan dengan kenaikan dari pajak daerah yang lainnya melalui perbaikan perencanaan, pengelolaan, dan pengawasan dalam pelaksanaan pemungutan pajak hotel; (2) BPKD Kota Sukabumi untuk meningkatkan efektivitas dan efisiensi pemungutan, upaya yang dapat dilakukan adalah dengan meningkatkan penerimaan dan mengurangi biaya yang tidak berkaitan dengan pemungutan pajak hotel serta dilakukan perbaikan pada beberapa hal yaitu kualitas sumber daya manusia dan sarana prasarana yang ada. (3) Penelitian serupa lebih disarankan untuk memperluas kajian yang lebih mendalam mencakup perhitungan potensi pajak hotel dan faktor-faktor yang mempengaruhi pajak hotel.

\section{REFERENSI}

[BPKD] Badan Pengelolaan Keuangan Kota Sukabumi. 2016. Laporan Realisasi Pendapatan Kota Sukabumi 2011-2015. Sukabumi (ID): Badan Pengelolaan Keuangan Daerah Kota Sukabumi.

[BPS Provinsi Jawa Barat] Badan Pusat Statistik Propinsi Jawa Barat. 2016. Statistik Hotel dan Akomodasi Lainnya Propinsi Jawa Barat . Jakarta (ID): BPS Provinsi Jawa Barat.

Enggar DPA., dan Sri R, Wahyudi I. 2011. Analisis Efisiensi dan Efektivitas Penerimaan Pajak Daerah Propinsi Jambi. Jurnal Penelitian Universitas Jambi Seri Humaniora, 13(1): 6982.

Fahik, RPAS. 2009. Penghitungan Potensi Pajak Hotel Dan Restoran Tahun 2008 Di Kabupaten Kudus [Tesis]. Jakarta (ID): Universitas Indonesia. 
Fery, Devianty. 2013. Analisis Kontribusi Pajak Daerah Terhadap Pendapatan Asli Daerah di Kabupaten Musi Banyuasin. Jurnal Ekonomi dan Informasi Akuntansi, 3(2): 137-151.

Handoko, S. 2013. Analisis Tingkat Efektivitas Pajak daerah sebagai Sumber Pendapatan Asli Daerah Kota Pontianak. Jurnal Ekonomi Daerah, 1(1): 1-17

Hoque, Z., and Adams. 2008. Measuring Public Performance. Goverment Departements Aust.

Ikeji, Chibueze C. 2011. Politics of Revenue Allocation in Nigeria: A Reconsideration of Some Contending Issues. Sacha Journal of Policy and Strategic Studies, 1(1): 121-136.

Ismail T. 2011. Paradigm Change of Local Tax. Journal of administrative Science and Organization, 18(1): 34-42.

Juri M. 2012. Analisis Kontribusi Pajak Daerah dan Retribusi Daerah Terhadap Pendapatan Asli Daerah (PAD) Kota Samarinda. Jurnal Eksis, ISBN 0216-6437. 8(1): 2020-2031.

Lengkong V. A., Saerang D. P. E., Sabijono H. 2016. Analisis Efektivitas Realisasi Pajak Hotel dan Kontribusinya Terhadap Pendapatan Asli Daerah Pada dinas Pendapatan Daerah Kota Bitung. Jurnal berkala Ilmiah efisiensi, 16(3): 896-907.

Mahmudi. 2010. Manajemen Keuangan Daerah. Penerbit Erlangga. Jakarta.

Marimin, Maghfiroh. 2010. Aplikasi Teknik Pengambilan Keputusan Dalam Manajemen Rantai Pasok. IPB Press.

Mustika WA. 2014. Kontribusi Pajak Daerah dan Retribusi terhadap Pendapatan Asli Daerah di Pemerintah Kota Surabaya. Jurnal Ilmu \& Riset Akuntansi, 3(6): 1-24.

Nuryani SE. 2010. Analisis Pajak Hotel Di Kabupaten Badung [Tesis]. Jakarta (ID): Universitas Indonesia.

Norregaard J. 2013. Taxing Immovable Property: Revenue Potential and Implementation Challenges. IMF Working Paper, 13(129).

Octovido I. 2014. Analisis Efektivitas dan Kontribusi Pajak Daerah Sebagai Sumber Pendapatan Asli Daerah Kota Batu. Jurnal Administrasi Bisnis (JAB), 15(1): 1-7.

[Pemkot Sukabumi] Pemerintah Kota Sukabumi. Peraturan Daerah Pemerintah Kota Sukabumi
Nomor 7 Tahun 2011 Tentang Pajak Hotel. Kota Sukabumi(ID): Pemkot Sukabumi.

Poulson, B. W., and Kaplan, J. G. 2008. State Income Taxes and Economic Growth. Cato Journal, 28(1): 53-71.

Pujiasih, R., dan Wardani, D. K. 2014. Analisis Potensi, Efektivitas, dan Kontribusi Pajak Hotel terhadap Pendapatan Asli Daerah Kabupaten Sleman. Jurnal Akuntansi, 2(1): 43-54.

Rusmana, O., Sularso, H., and Chandraningrum, F. 2011. The Impact of Fund Transfer, Government Expenditure and Government Auditor Opinion on the Level of Corruption in Indonesia. Journal, pp: 1-29.

Sahroni, R., Hamid, D., dan Iqbal, M. 2015. Strategi Peningkatan Pendapatan Asli Daerah (PAD) Melalui Pajak Daerah di Kota Malang. Jurnal Mahasiswa. Perpajakan, 2(2): 1-10.

Sepuvelda, C. F., and Vazquez, J. M. 2011. The Consequences of Fiscal Decentralization on Poverty and Income Equality. International Studies Program Working Paper, 29(2).

Tang B., Wong S. and Liu S. 2011. Institutions, Property Taxation and Local Government Finance in China. Issues of Urban Studies, 48(5): 847-875.

Utama AM. 2009. Strategi Peningkatan Pendapatan Asli Daerah Kabupaten Lampung Barat [Tesis]. Bogor (ID): Institut Pertanian Bogor.

Wijayanti TL. 2012. Analisis Kontribusi dan Proyeksi Jenis-Jenis Pajak daerah di Kabupaten Ngawi[Tesis]. Surakarta (ID): Universitas sebelas Maret.

Wirdianto E, Elpira U. 2008. Aplikasi Metode Analytical Hierarcy Process. Jurnal Teknika, 29(2): 0854-8471.

Yunanto L. 2010. Analisis Potensi, Upaya Pajak, Efisiensi, Efektivitas dan Elastisitas Pajak Hotel di Kabupaten Klaten [Tesis]. Surakarta (ID): Universitas Sebelas Maret.

Yuliani S. D., dan Hidayat K, Topowijono. 2015. Analisis Laju Pertumbuhan Dan Kontribusi Penerimaan Pajak Hotel dan Pajak Restoran Terhadap Pendapatan Pajak Daerah (Studi Pada Dinas Pendapatan Daerah Kota Malang). Jurnal Perpajakan (JEJAK), 1(1): 1-6. 